\title{
The Military Coups in Shadow of Democratization (A Comparative Study of Turkey and Mauritania)
}

\author{
EkramBadr El-din ${ }^{1} \&$ Mohamed Dit Dah Ould Cheikh ${ }^{1}$ \\ ${ }^{1}$ Faculty of Economics and Political Science, Cairo University, Cairo, Egypt \\ Correspondence: Mohamed Dit Dah OuldCheikh, PhD Candidate in Faculty of Economics and Political Science, \\ Cairo University, Cairo, Egypt. E-mail: dahouldcheikh76@gmail.com
}

\author{
Received: July 31, $2017 \quad$ Accepted: August 16, $2017 \quad$ Online Published: September 28, 2017 \\ doi:10.5539/ass.v13n10p75 URL: https://doi.org/10.5539/ass.v13n10p75
}

\begin{abstract}
The current study tries to examine the military coups that have occurred in Turkey and Mauritania. These coups differ from the other coups that occurred in the surrounding countries in the phase of democratization as these coups served as a hindrance to the process of democratization in Turkey and Mauritania. The problem of the study revolves around the analysis of the coups that happened in Turkey and Mauritania in the phase of democratic transition. The research is designed to answer the following question: what are the reasons that prompted the military establishment to intervene in political life in the shadow of the process of democratization in Turkey and Mauritania? The study aims at understanding reasons that pushed the military establishment to intervene in the political life. To discuss this phenomenon and achieve the required results, the analytical descriptive approach is adopted for concluding key results that may contribute to understand reasons that pushed the military establishment to intervene in the political life in Turkey and Mauritania in the aftermath democratization occurred in the two countries. The study concluded that the military establishment in both countries engaged in the political action and became ready to militarily intervene in the case of harming its interests and acquisitions.
\end{abstract}

Keywords: Mauritania, democracy, military coups, power rotation, democratization, political stability, Turkey

\section{Introduction}

Based on what has been mentioned above, this study tackles and analyzes the successful military coups launched in Turkey and Mauritania during the process of democratic transition, which resulted in the circulation of power in a non-peaceful manner during the democratic phase. In this context, this study is divided into two parts: the first part focuses on the reasons of coups in the two countries. The second part focuses on the effects of coups on democratization in both countries.

\section{The first part: the causes of military coups in Turkey and Mauritania}

This part deals with the causes that pushed the military coup to intervene in the political life after democratization in Turkey and Mauritania.

\subsection{First: Military Coups in Turkey after the stage of democratization}

The Turkish military establishment has historically enjoyed an outstanding position and a key role in the political life. Since the establishment of the Ataturkian Republic in 1923, Ataturk focused on this position and role especially in the wars of independence that preceded the foundation of the republic. The role of the army continued in the political life because the army regarded the protection of Ataturk's ruling principles, as a part of the Turkish state's character, as one of its jobs and duties. Ataturk's ruling principles were about the two values of secularism, and the independence and unity of the state. Based on this military duty in the protection of the two values, the Turkish Republic witnessed many military coups, which were harmful to the democratic record of Turkey on the one hand and the Turkish democratic achievements on the other hand.

\subsection{The causes of the military coups in Turkey}

After the death of Ataturk, although the presidency of the Turkish state was separated from the leadership of the army, the army stayed the foundation of a special character which supervised and monitored the political process and intervened to adjust it temporarily if it felt that it tended to threatening secularism and Kemalism (Habib, 
2005).

The Turkish army staged three military coups in 1960, 1971, and 1980. Then, it staged a soft coup in 1997 which led to force NecmettinErbakan then to submit his resignation. Recently, in the era of the government of Justice and Development Party, the Turkish army was about to stage a coup which some people called "the electronic coup" in 2007. The coup was as a statement in which the army warned the ruling party of nominating Abdullah Gul as president of the Republic in addition to the last trial of coup in 2016.

A static has shown that Turkey from 1932 till 1987 was ruled by the martial law for five and twenty years and nine months, equivalent to forty per cent of the life of the republic (NourEdin, 1998).

\subsection{The Coup on 27 may 1960}

The Turkish army staged the first coup in the second half of the twentieth century on $27^{\text {th }}$ May, 1960 . The Turkish army declared its reasons for taking power which were outlined as follow: prohibiting the Turkish people who killed each other and saving the parties from the contradicting situation in which they fell. The analysts saw that this coup was not as a result of the prevailing circumstances in Turkey in the short period of time before 1960 when the extremists in the army who had the desire of staging a coup prepared for it since years. Their arrangements were divided into two divisions: First: their eagerness that their supporters take the high loading positions in the army. Second, searching for one of the army's leaders "so as to lead their movement to gain the support of the rest of the armed forces". They succeeded in their quest and found what they were looking for in the General GemalGursel (Zurcher, 2004).

\subsection{The Causes of the coup of 1960}

As for the reasons for the resentment of the army which planned for the coupd'état against the government, some said that it was attributed to the fact that the government of the Democratic Party harmed the social situation of the army. Journalists in a daily newspaper discussed with the most outstanding military figure joining in the coup. Their discussion about their reasons for staging a coup against the government was always including the matter that the democrats insulted them. On the other hand, journalists noted that the military coup was a natural result for the trials of both the democratic government and the republican opposition to attract the army to get its support. The different Turkish forces strongly attracted the army to the political arena which it was always eager to be away from (Dipsar, 2008).

The lack of appreciation of the Democratic Party to the prestige and importance of the army was highlighted in important statements for the then prime minister, Menderes, who threatened of getting rid of the pride of the corps of officers and declared that he would, if he wanted, appoint the army's leadership of the reserve officers (Donilof, 2001). In addition, one of the problems of Menderes' policy was the contradiction with the soul of secularism in addition to the difficulties that journalists and activities faced in their dealing with him for authoritarianism (Asfour, 2011). The coup was an expected result of the politicization of the army which was exercised by both the government and the opposition. Some researchers added external factors to the internal factors which led to the coup: the repercussions of joining NATO prompting the army to "modernization" process and creating factions inside the Turkish army which were different in the "technological" and "generational" aspects (Aslon, 2001).

The signs of the army's discontent of the government emerged since 1954 when a few number of officers began to criticize the policies of the democrats. Then, this stereotype changed to be the prevailing behavior among the officers. The methods of expressing the resentment changed later from "a secret assembly that worked for the purpose of the fact that the army could regain its role, reputation and ability to solve the different problems of Turkey" (Donilof, 2001). By 1960, it was staged a non-recurring coup in any military coup in Turkey in terms of the ranks the officers who staged the coup. They were not the leaders of the army. In fact, they were the officers of low ranks (Abdel Galil, 2001).

The coup number thirty eight (The Commission of National Unity) began their era by going to the parliament to swear as follow:

I pledge to serve the Turkish nation without expecting getting any bonus and without any other motives except the principles of ethics, justice, law, human rights and according to my consciousness. I will work for nothing except the prosperity and sovereignty of my nation. I will not deviate from the aim of originating the republic in the new constitution and transferring power to the new parliament. For this, I vow and swear by my honor and all what is sacred.

It was undeniable that they had already withdrawn to their barracks and handed over power to civilians "although the re- establishment of a constitutional government required eighteen months instead of the two or 
three expected months (Weiker, 1980).

In addition to the previous reasons, the words of one of the leaders of the coup, OrhanArkanali, were on the reasons for the coup:

The group that ruled Turkey after 1954 deprived the people of all its rights. It deceived the nation and dragged it to an economic and social destruction. The ruling group forgot the ethical values and forced the Turkish people to forget them. The establishment of the state changed to be a tail of the party's organization. Therefore, the pride of the Turkish armed forces, the only organized force in the country, was harmed on every occasion and even their uniform, which was their historical heritage, became a stigma to those who wear it (Mahfoud, 2008).

Therefore, this coup was attributed to the governmental failed policies, partisan conflicts and threats to the values of society. The coupists did not try to deny that insulting the armed forces by the government of the democrats was the main reason for overthrowing the government.

As for the promises of the political reform, the words of GemalGursel were as follow:

The revolution of the Turkish Armed Forces on $27^{\text {th }}$ May was not as the revolutions of the other Middle East countries. While those revolutions were aimed at establishing dictatorships, the Turkish revolution established democracy and would hand over power to the party winning elections in mid-October, 1961. All parties would be given the right to participate in elections. Free elections would be held (Ahmed, 2014).

Thus, the position of the army was clear and the army was committed to the principles of the safeguarding army declaring that by the time of the elections in the following year, it would open the way for the free competition so that the people chose who would represent it. At that time, the army would feel that it completed its mission and could go back to the barracks.

\subsection{The coup on 12 March 1970}

Like Europe, Turkey was affected also the student movements in 1968 as movements that emerged in the form of innocent student demands. Then, they gained political and ideological content. Thus, they turned into bloody terrorist operations. Under the pretext of putting an end to terrorism, the military commanders staged the coup on 12 March 1971 (Sheta, 1989).

The first government of the transitional authority was formed by NehadArim who resigned from the Republican People's Party. The government decided to declare martial law. Tanks went to the streets of Istanbul. The campaign of arrests was expanded. Military courts were formed and expanded issuing the newspapers magazines of the Left. However, the anti- political forces activities did not stop. In contrast, they expanded to include peasants and persons who demanded agricultural reform, the Kurds of the eastern states demanding their national and constitutional rights (Doughan, 2006). The noisy student demonstrations expressed their demands accompanied by acts of political violence between right-wing groups and radical forces. Turkey almost sank in a wave of troubled disturbances. The National Order Party, established in January 1970, was closed under the constitutional court decision on $20^{\text {th }}$ May 1971 and the political life of the party ended because it violated the principles of the Turkish Constitution (Eljmil, 1997).

\subsection{The Coup on March 1980}

The coup of September 1980 was an expected result of the state of anxiety and fears of the army's leaders. The intention to intervene was available for the army's leaders before this date, but they delayed the date of determining the time of the coup precisely. These secret agreements were clear in the framework of the army. They were official when the General Evren directed to the state's president and submitted to him an official letter aimed at expressing the army's discontent because of the deterioration of the security situation in Turkey. The letter also included the trial to urge the state's president to take all the required procedures to overcome this bad situation (Zahra, 2016).

\subsection{The Causes of the Coup of 1980}

At the outset of 1980, the political and economic state in Turkey reached the peak of its crisis and complexity. In fact, the crisis began to worsen since the beginning of 1977. None of the governments that were formed in this period could find a solution for the crisis. During this period, the economic and social problem of Turkey worsened as a result of the expenses of the Cyprus war, the increase in the oil prices, depending on the importation, the increase in the Turkish debts and the totally imbalance of the Turkish budget. To overcome this crisis, the government imposed more taxes, increased the prices of many of necessary commodities, and began to print banknotes to be able to pay the increases that it determined in the salaries of the employees and labors. In such a desperate situation, the government began to beg the countries and the international banks to buy the oil 
necessary for the daily usage (Eseyed, 2001).

The country was experiencing an increasing emergence of violence, a flow of weapons that nobody knew their source, murders, assassinations, and kidnappings by some Marxist groups. The National Movement Party by the leadership of (Turkish) had a role in the acts of violence. There was an increase in the armed attacks on the members of the political parties, the killing of a number of the political figures, officials in ministries and the governmental bodies. Additionally, the political instability had an effect on such terroristic situation. From January 1971 till December, 12 governments were formed, that was, an average of one government every 9 months (Eseyed, 2001).

As per the most important motive of the army's intervention in authority, as it was seen by the very commander of the coup and mentioned in one of his speeches in 1987, it was the desire of the people: "The armed forces do not stage coups without causes. The coups are staged on the basis of the appeal of the people. The intervention which took place on 12 September 1980 was implemented very reluctantly only because the nation requested it 9 (Stevenc, 2009).

In relation to the arrangements of staging the coup, they began when Evren conceived of an army that may be forced to capture power. It was expected that all people had content of the necessity of the army's intervention "because history showed that the intervention which began before the knife cut deeply to reach bines, its harms would be more than its benefits. Evren thought that in the case of the absence of the political parties' support and the cultured elite, the coupists ought to depend on, according to his words, the nation. To grant its support, the nation must believe also that there was no way to overcome the crisis except the intervention. The way to be sure about that was founding a group of study to submit a report about to what extent the necessity to the intervention. This was what was asserted by the report, according to Evren's words. However, Evren did not rush to take the decision and sent a written warranty to all political and constitutional establishments in Turkey. Although Evren believed that his decision was not fruitful warranty, he insisted on the decision to show all people that he exerted much effort to adjust the situations without resorting to the intervention in power (Demirel, 2004).

All these introductions resulted really in staging a military coup d'état on $12^{\text {th }}$ September, 1980 followed by all the measures that would paralyze the political life, lead to the state of emergency in the country and suspend the work of the parliament and political parties. Although this coup d'etat and the other coups are similar in terms of their repercussions, the commentators noted that this coup was distinctive from other coups in terms of planning and arranging in an orderly manner which appeared even in the choice of timing. The coup d'état was staged when it was appeared that there was no other alternatives (Theracky and Findling, 2001).

The statement of the coup commander explained the causes of the coup which stemmed from a strong belief in the democratic system that did not have the appropriate laws to depend and protect itself from terrorism and extremism. In fact, it was a trial to educate students "political, right and retroactive ideas" rather than Ataturk's ideas (Dnilof, 2001).

As for the presence and absence of the indicators of the partial withdrawal in the period of the military rule, the indicator of the constitutions and laws emerged. In October 1980, the military regime adopted a provisional constitution and stated that, on the condition that these articles are consistent, the 1961 constitution will be operative until a new constitution is drafted (Theracky and Findling, 2001). Then, a referendum was held on taking executive power and the legal framework of the state. In an expressive description for this referendum, in which the people chose the new constitution and the new president simultaneously, it was clear that people, who were in charge of the propaganda of KenanEvren, succeeded in portraying an image to this referendum as it was a choice between the new constitution (Yes) and chaos (No). It was not clear whether the high positive vote for the constitution or for EvrenPersonally (Rumpf, 2011). General KenanEvren was elected, as the commander of 1980 coup d'état, as president of the republic for seven years under this referendum. It was clear that the military personnel who developed the constitution hoped that the successor president of Evren would be a former military person or at least a civilian who was acceptable to the army (Ozbudun, 2011).

\subsection{The Second: The military coups in Mauritania after democratization}

The Mauritanian case, that is to say the army's relationship with the state and that democratic transition, offers distinct experience at both the African and Arab levels. An intense debate has been sparked off on the Mauritanian army and where it stands from the democratic transition, the extent to which it has been able to lead the process and whether it has been a major obstacle to that democratic process or not. The coup launched on August 3,2005, in the eyes of many researchers, was likely to presuppose the possibility of the army to lead such democratic transformation in a country. However, Mauritania did not wait long to support the likelihood of the second assumption of a subsequent coup in 2008 , which exposed a deep problem in the civil military relations, 
namely the extent to which the military leadership is able to submit to political leadership if it is involved in a political conflict of interests, making clear the extent of the professionalism of the army in the developing countries, including Africa.

\subsection{Causes of the military coup in Mauritania}

Military coups have been a milestone in Mauritania's modern political history and are more unique to Mauritania than to the other Arab and Islamic political regimes. They are a deviation from the successive Mauritanian constitutions, the last of which was approved on July 20, 1991, and it affirmed the democratic system and multi-party system. Such military coups have been violations of constitutional legitimacy, democratic process, the electoral law to choose the president and mechanisms of political participation.

\subsection{The coup of 3 August, 2005}

The first precursors of the coup were when the units of the Mauritanian army rose up at the dawn of $3^{\text {rd }}$ August, 2005, and declared the overthrow of President MaaouyaOuldSidi Ahmed El Taya. It was a peaceful coup characterized by tolerance and non-violent manifestations of power. A council was formed to take over in the transitional phase and it was known as "The Military Council for Justice and Democracy" headed by Colonel Ely Ould Mohamed, the coup leader who had been serving as the Director General of National Security since 1985. Also, the council included 18 members; 17 colonels and one navy captain. This council seized power until power was handed over to an elected civilian president in Mauritania in 2007 (Ndiaye, 2006).

In this part we will discuss the real causes of the 2005 Mauritanian coup d'état with a focus on the internal responses.

\subsection{Causes of the coup of 2005}

The Mauritanian Army came to power again after nearly fifteen years when President OuldTaya, who had remained in power for about twenty years (1984-2005), was overthrown. A new page of the contemporary political history of Mauritania was turned bringing the democratic transition process in Mauritania to a halt after the approval of the political pluralism in 1991.

On November 27, 2000, Major SalehOuldHanenna headed the first failed coup after that phase of democratization. This happened ten years after the last coup against OuldTaya's regime. This attempt failed due to Major SalehOuldHanenna's defamation which led to his arrest. He was charged of the assassination of the president. However, he and his men were released after his imprisonment for two months. Later, OuldHanenna carried out a second coup attempt in 2003, in coordination with low-rank officers in the army, but they failed because of some difficulties that led to the death of a number of citizens and members of the National Army, including the National Army Chief Mohamed LemineOuldEnjian (Mohamed Ahmed 2011).

Then there was another coup attempt in 2004; it was the third coup attempt by Hanenna. He was arrested and the attempt was thwarted. Moreover, he was sent to the military court with (192) of his supporters and was sentenced to life imprisonment. After seven failed coups against Taya, the last coup succeeded on the third of August 2005 when Taya was outside the country. The coup was led by Ely Ould Mohamed Fall, the Colonel Director of Public Security. This ended the rule of OuldTaya after a period of 21 years during which a lot of things happened as the official political scene had revolved around the figure of the president OuldTaya; he was a key element surrounded by some figures who shared one goal of acquiring material and political benefits. Also, his supporters looked upon him as an ideological umbrella to shelter everyone (Al-Qalam, 2003).

Back then Mauritania faced a terrible political crisis, as the regime had been collapsing, especially at the political and security levels, since the failed coup attempt on the $8^{\text {th }}$ and $9^{\text {th }}$ of June, 2003.

Some of the manifestations of this confusion were demonstrated in terms of doubt towards the opponents of the regime. Thus, many Mauritanian politicians were put in prison with charge of plotting to overthrow the regime. The same period also witnessed unprecedented security upheaval, and Salafist groups were accused of being behind this lawlessness, which reached the heart of the capital, where these groups and security forces exchanged fire in direct confrontation. Also, the Mauritanian military garrisons were attacked by Salafist groups, and, furthermore, a number of soldiers were killed and many vehicles, weapons, and ammunition were stolen during the Salafist attack on the Garrison of Lemgheity (OuldHaidalla 2012).

The head of the Supreme Council for Justice and Democracy described what happened and said: the change that happened on the $3^{\text {rd }}$ of Aug, 2005, has put an end point to the political regime that governed Mauritania for more than four decades and it was not in favor of anyone. In fact, what Mauritania is experiencing today or what it experienced before Aug 3, 2005, is the product of 45 years of one-party system and autocracy (Al-Magala, 2007) 
Political corruption and mismanagement: the reign of President OuldTaya was characterized by the spread of corruption and mismanagement to the extent that the citizens lost faith in the decisions of President OuldTaya's governments and came to the conclusion that the public service was just a way to achieve personal and material benefits; senior positions were held by unqualified people based on personal or tribal links that are irrelevant to considerations of efficiency and professional integrity. This led to the application of the tribal standards on administrative and political sets opening the way for more corruption in the absence of any censorship or accountability (OuldSidi Baba, 2005).

Economic reasons: the economic policies pursued by President OuldTaya, including the standards of living within the state, and this motivated the military institution to overthrow the president. Perhaps the most important economic reasons are:

A) The misusage of wealth and economic resources of the state, being in the hands of a small group related to the president. Also, it is worth mentioning that many minerals were discovered in Mauritania, especially during the rule of President Maaouya. Moreover, more oil discoveries were made. However, this wealth was controlled by men surrounding President OuldTaya who took all the revenues (Bayoumim 2005).

B) The deterioration of economic conditions and the decline of living standards and such economic conditions have reached even the military, as the soldier's salary was equivalent to $\$ 40$ per month, which was unfair especially amid the rising prices (Shafei, 2006). That was possibly due to the policies pursued by President OuldTaya, which followed the instruction of the Bretton Woods institutions (IMF and World Bank) related to the application of economic reform and structural adjustment programs, and the adoption of privatization policies under the pretext of lessening the burden on the state budget, which had a negative repercussion on the living standards of the citizens and resulted in overthrowing the president's regime (OuldSidi Baba, 2005).

- Marginalizing the role of women and ignoring the category of the Haratines: some segments of the community suffered from marginalization during the reign of President Maaouya. Indeed, women represent one of the prominent segments which had not received the representation it deserved, in the government or in the administrative apparatus of the state, or even in the Parliament. The decision that was taken by the Military Council for Justice and Democracy, which led the country after the 2005 coup, to allocate $20 \%$ of the seats in the parliamentary and municipal councils to women, was a reflection of its keenness to provide an opportunity for women after long years of political neglect by President Maaouya (MohiEldeen, 2014). In addition, regarding the Haratines category, they are black Arabs who had been slaves in the past but were freed later. Nonetheless, they faced injustice and oppression during the reign of President Maaouya, and, to some extent, they decided to seek opportunities so as to gain their political rights of which they were deprived for years (Belkeziz, 2005).

Also, among the causes of the 2005 coup was the normalization with the Zionist entity in 1999. This move was seen by many analysts as the beginning of the end of Taya's regime (Al SayehMubbarak, 2013) and was confronted with considerable opposition from Mauritanians who went out in marches condemning the move, which they considered as an act of betrayal itself. This put Taya's regime in embarrassment, nationally and globally. Also, the regime did not provide objective justifications for taking this move, which came after secret meetings between the two parties led by Washington. This came after severing the Mauritanian relations with France, and this was one of the reasons for the downfall of the OuldTaya's regime, and was seen by many analysts as a main and direct reason for the coup of 2005. It is not a secret that France brought Taya to power on the $12^{\text {th }}$ of December, 1984 (MohiEldeenMohmmad Mahmoud, 2014).

\subsection{The coup of 6 August, 2008}

A series of events and attitudes regarding political, economic, and social decisions contributed to the military coup against the elected president SidiOuldCheikhAbdallahi on the $6^{\text {th }}$ of August 2008, 16 months after he had come to power. Perhaps the most important causes were:

\subsection{Causes of the coup of 2008}

- The conflict that took place between the president and the members of parliament: the conflict intensified between President SidiOuldCheikhAbdallahi and his opponents; SidiOuldCheikhAbdallahibreachED the most important constitutional requirements adopted to prevent the President from taking the side of any party. Besides, SidiOuldCheikhAbdallahi was about to form a political party and chose the leader who was the prime minister back then in a move that appeared to be an attempt to make his supporters side with him. The political process in Mauritania was largely a negative one, and things got worse by the actions of the president (Safinar Mohamed, 2005), especially after some members of the parliament had called for a meeting with the Senate to discuss what they called a private corruption charge against the president's wife, who presided over one of charitable 
institutions in the country, as well as their opposition to the performance of the Prime Minister's government YahyaOuld. Those members also called for the formation of a second government. In a move that escalated tensions between the legislative and the executive authorities, it was announced that 25 out of 48 MPs had withdrawn from the National Assembly party. Also, 23 out of 41 MPs had given up the ruling party. Perhaps, this was the reason why the ruling party had lost the parliamentary majority. This also had weakened the President SidiOuldCheikhAbdallahi's position in the political arena in Mauritania (Al Qarawi, 2013).

The government failed to reach any kind of serious dialogue with the opposition forces, whether to participate in the Parliament or to remain outside it. The government did not do any step towards absorbing the opposition forces, and this led to a collision that made it impossible for the different parties to work together to serve the higher interests of the country.

- OuldCheikhAbdallahi included some opposition parties and some of the former regime elements in the government, which infuriated the military leaders (Shafei, 2008).

- There was tension in the relationship between the president and the military institution: a number of factors contributed in creating a state of tension in the relationship between the president and the military institution. Perhaps, the most important factor was that the military was dominating the presidential institution due to several justifications given by the military. One of these justifications was that the president lacked the political acumen needed to carry out his duties efficiently and effectively, and that the military played a significant role in giving the power to the president in the 2007 presidential election (OuldBabana, 2014).

The influence of the military leaders became obvious on the presidential palace and thus on the political area in Mauritania. All this gave rise to the militarization of the political life in Mauritania, and the army was in control once again to prove that there were no civilian or political forces in the Mauritanian society that could get beyond the army's power and position. Amid the absence of a democratic and pluralistic system that regulates the peaceful transfer of authority and identifies at the same time the role and functions of the Armed Forces to defend the territorial integrity of the state (Ould Mohamed, 2013).

We can say that the elections that took place on the $23^{\text {rd }}$ of November 2013 were the most important indicator of the intervention of the army in the political life, where it took these two main tracks:

Path of candidacy and coordination within the supporters of the majority: where it made active senior military leaders in political mobilization and selected some tribal groups so as to address them directly in the capital Nouakchott in an attempt to show political support for the ruling party. By doing this, they enabled the generals and senior military commanders and security institutions to constitute the majority of the Parliament (OuldBabana, 2014).

Path of influencing the list of voters and the transfer of military battalions to vote in areas that the party did not rule, where thousands of officers from the military voted in El Kesar province in the capital Nouakchott, the municipalities of Alek, Kermasene, and Odan in favor of the regulations of the ruling party (Mannaa, 2008).

- Prevalence of corruption and weak government performance: the short period of time that the President SidiOuldCheikhAbdallahi ruled witnessed the spread of corruption, and there were numerous rumors about the president's desire to monopolize governance. Also, the appointment of his relatives in important positions was provoking. Also, there were those financial scandals that began hovering around the charitable organization that was headed by his wife and his son was the General Secretariat of the organization (Safinar Mohamed, 2005).

On the other hand, President OuldCheikhAbdallahi formed a technocratic government and its Prime Minister was ZeinOuldZidane. This government was disappointing to the citizens, as it was characterized by the predominance of non-homogeneity and the majority of tribal considerations, in which its impact was reflected on the decline of the political and economic mechanisms, which made the government unable to cope with major problems related to citizens in Mauritania, such as unemployment and other problems. All this gave justifications to the military intervention under the pretext of saving the country from these dangers (MohiEldeen, 2014).

- Deterioration of economic conditions: economic conditions deteriorated more under the rule of President OuldCheikhAbdallahi and the return of the symbols of corruption who were part of the political system during the reign of the former President MaaouyaOuldTaya. Plus, oil revenues dropped by $85 \%$ in that year. In this context, Mauritania was ranked 137 among 177 countries in the Human Development Report of the United Nations. There was also that significant deterioration of the food services in the country, especially with the rising prices in the world (Shafei, 2008). According to a report issued by the UNICEF, $12 \%$ of Mauritanians suffered from malnutrition back then and lit was not possible to save $15 \%$ of food they needed. The country witnessed a revolution of hungry people in November 2007, where demonstrations swept many cities in protest 
against the terrible rise of the prices of food commodities. Although the government took several measures towards this problem, such as providing an estimated 12 million dollars to cope with the rising prices and creating more job opportunities for young people. However, these measures were just painkillers and did not rescue the government that was headed by Zidane. Therefore, Zidane resigned in May 2008 (MohiEldeen, 2014).

-Deterioration of social conditions in the country: Perhaps, one of the most prominent manifestations of this deterioration was the appearance of many excluded groups that wanted to take advantage of any political or economic gains given to all other categories. These excluded groups are represented in both Haratins (former slaves) and Negroes who made up about $18 \%$ of the country's population; they suffered from injustice and exclusion during the reign of President MaaouyaOuldSidi Ahmed Taya. Although the government of the toppled President SidiOuldCheikhAbdallahi executed some corrective measures regarding this matter, such as the issuance of anti-exclusion and slavery law in August 2007, this law was met by resistance by some Mauritanian tribes to the extent that it looked like it has not been in force till now (Al Qarawy, 2013).

In addition, the international dissatisfaction towards President OuldCheikhAbdallahi, especially in France, was also one of the things that helped the coup. The world community was an obstacle in the way of the president's return to power. Perhaps this was due to a set of internal actions taken by the president that contributed to increasing the tension and provoking accusations about his serious and permanent attempt to increase the influence of political Islam. Some of these measures were:

- The release of all Salafis.

- Giving the Islamist political party legal political authority.

- Building a mosque in the presidential palace.

- President OuldCheikhAbdallahi sought to build a strong political regime away from the army commanders.

- The President Sheikh Abdullah had the audacity to threaten Israel through his announcement of putting the diplomatic relations with Israel to referendum, and there was a fear of carrying out this threat, which was accepted by the majority (Safinar Mohamed, 2005).

Moreover, he gave three ministerial portfolios in the first Ould El Waqef government (July 2007) that had Islamic tendencies.

The researcher believes that these measures enhanced the level of political participation and openness to opposition, which was supposed to be for President SidiOuldCheikhAbdallahi's own good.

\section{The second part: The Effect of the Military Coups on Democracy in Turkey and Mauritania.}

This part deals with the effect the coups on democratization in the two countries.

\subsection{The First: Turkey}

The coups staged in Turkey had negative effects on the prevailing democratization process despite the data and causes mentioned by the coupists. In 1960 coup, it was noted that the army marched to the headquarters of the Democratic Party and the Government on $27^{\text {th }}$ May, 1960 . Nine and thirty military officers were at the top of the coup and formed the so-called "National Union". They declared that they were judging among the different powers and they would not be rulers. Although the coup was without bloodshed, once its leaders stabilized, the leaders of the Democratic Party were arrested. Menderes, Hassan Poladkan, minister of finance and FatihRoshdiZorlu, the foreign minister were executed. Also, Jalal Bayar was sentenced to death and the sentence was mitigated to life imprisonment because he was an old man. Manderes was accused of high treason because he betrayed the principles of Ataturk. The trial focused on his relationship with one of the Islamic groups called "The Movement of Light" (Hassen, 2012). The newspapers published exchanged letters between Menderes and the head of the group, the Kurdish Sheikh "SaeedNursi". He talked to the head of the party by a tone of exaggerated respect in which he used to talk to the Sheikh. The trials focused on a general accusation of the Democratic Party that it wanted to make Turkey go back. In other words, he wanted Turkey to go back to Islam. He did not dare to disclose for fear of popular outrage. Thus, the coup officers tried to revive Kemalism but cautiously. The words of the coup commander, GemalGrrsel, expressed that when he was standing at the tomb of Ataturk and said: "Great father, allow us to follow your way appropriately". He meant by these words following the path of secularism and of course the dissolution of the Democratic Party on Sept. 29, 1960 (Sheta, 1989).

\subsection{The Coup of 12 September 1980}

The leaders of the coup of September 12, 1980, were not better than their predecessors. They closed the Grand National Council of Turkey, and arrested the heads of the political party and a number of representatives and 
leaders of unions: the head of the Justice Party, SüleymanDemirel, the head of the Republican People's Party, BülentEcevit, the head of the National Safety Party, NecmettinErbakhan, and Alp Arslan Turkish. The country witnessed a large wave of arrests including leaders and members of youth organizations (Zahra, 2016).

During the period of military rule, 178,565 persons were detained, 64,505 were arrested and 41,727 were sentenced for various reasons. 326 persons were sentenced to death. Only 25 verdicts were executed (Mountaser, 2015).

Despite declaring the new constitution draft on October 14, 1982, which was overseen by a committee of fifteen experts and in cooperation with the National Constituent Assembly which aimed at bringing Turkey back to the democratic system. Simultaneously, it was asserted that Turkey would not drift again into chaos in which it was flooded in the years before the last coup (Hasen, 2012).

The constitution included a provisional clause stipulating that all those who were in power on September 12, 1980 were banned from participating in political activities for ten years and those who were members of the Grand National Assembly of Turkey for five years. It was the end of an important stage in Turkey's internal political behavior. The 1982 Constitution referred to education. Under the constitution, education, teaching religion and morality were under the control of the state, followed by all the measures that led to paralyzing the political life, prevailing the state of emergency in the country suspending work in the parliament and political parties. Although this coup was similar to other coups in terms of its repercussions, the commentators noted that this coup d'état was distinguished from the other coups in terms of the fact that it was well-planned and well-arranged. It was clear in the choice of its timing. The coup was staged when "it was shown that there were no other alternatives" (Mountaser, 2015).

\subsection{Second, Mauritania}

The 2005 coup d'état had negative repercussions on democratization, the most important of which are:

The administration dependency on the military ruler: the military ruler has deliberately imposed his control over the state's administration since the first moments of his accession to power in the country. Therefore, the government was completely attached to the army to the extent that it lost its independent resolution, and that weakened its technical performance.

The formation of a new government: the ruling military council set up a civil government less than a week later after the coup, and it entrusted its presidency to Mr. Sidi Mohamed OuldBoubakr, who was Mauritania's ambassador to France. Perhaps, this is what confirmed suspicions that France played a major role in administering the coup, and OuldBoubakr served as a link between the putschists and France (Ndiaye, 2005).

Maintaining all the structures and policies of the former regime: the coup leaders kept all conditions and continued to use previous political, economic and administrative measures when they reached authority. That was one of the strangest moves in the history of military coups. The leaders of a military coup, after taking over power, usually resort to disrupt the constitution and develop completely different policies instead of the ones developed during the previous regime. This was contrary to what happened in Mauritania, where leaders of coups kept all the structures and policies of the former regimes. They only amended some provisions of the constitution. On the external front, they kept all the economic and political strategies of President MaaouyaOuldTaya, and they informed the Israeli ambassador that the decision of normalization was a win to which the leaders of coup should adhere.

The negatives of the coup of 2008 were manifested in some points:

- Mauritania came under the military rule again, and the role of the military coup was growing and this helped bring Mauritania under the military rule after 16 months of civilian reign. The text of the first statement issued by the coup leaders did not reflect a clear map or a specific timetable of the military plans to hand over power to an elected civilian government. The statement only canceled decisions taken by the ousted president concerning the military leaders. A new council was formed with 12 members and it was headed by the commander of the Republican Guards, General Mohamed Ould Abdel Aziz, without any limitation of the actual status of this Council in the political life or powers, or even the status of the constitutional institutions. So, we can say that the military was no longer willing to move away from the political life, so as to ensure that their rights would not be taken away by any person or entity even if they have the political legitimacy and international support, or even if they are supported by the military institution itself, as is the case of the ousted President SidiOuld Sheikh Abdullah (MohiEldeen, 2014).

- Escalating external interest in the Mauritanian army: the Mauritanian military coup in 2008 resulted in escalating global interest in the military institution, which became an active element in the equation of the 
political power in Mauritania. There are factors which led to the growing political role of the Mauritanian military institution. These factors are the weakness of the political elite and its division to contradictory and warring parties, the inability of civilians to run the political life with transparency, as well as their inability to manage their differences to prevent the country from the pitfalls of military intervention. Therefore, it can be said that the interested international powers in Mauritania will remain interested in the national army as it is the main guarantee to achieve their interests, and it is considered the protector of the rest of the civil institutions and economic sectors as well (Safinar Mohamed, 2005).

\section{Conclusion}

To sum up, the Turkish army, which saw itself as a guardian of Turkish democracy, did not stage a coup unless the reasons were given. In fact, its first objective was to protect secularism as an essential aspect in the ideology of the Turkish establishment. It was concluded by Samuel Huntington who said "in some Islamic countries, the choice was between anti-democracy secularism and anti-West democracy. He referred that secularism, as understood by the Turkish army, did not express understanding and respecting democratic principles. Although Erbakan did not threaten the democratic system, the Turkish military establishment overthrew it, which resulted in making many researchers consider the Turkish military establishment as an obstacle to entrenching democracy.

From historical experience, military coups have always been in the minds of the leaders of the Mauritanian military as a mechanism of non-peaceful circulation of power, regardless of the international and regional communities that no longer accept this mechanism even at the level of political discourse. Perhaps this scenario is justified in that the Mauritanian military establishment has been immersed in political work since the early years of independence, and this made the Mauritanian army ready to repeat the experiment, in the event of any practices that would prejudice the military leaders' gains or undermine their influence within the state.

\section{References}

AbdeGalil, T. (2001). The Islamic Movements in Contemporary Turkey: A Study in Thought and Practice. Cairo: Jawad Al Sharq for Publishing and Distribtion.

Abdel Galil, T. (2001). The Army's Officers and the Constitutions in Turkey: from the Iran Issue to the constitution without Army's Officers. Giza: Nahda House.

Ahmed, F. (2014). Turkey, the Quest for Identity. London: One World Publication.

Ahmed, M. H. (2010). Mauritania between the Military Coup and the Civilian Rule. Journal of Derasat Dawlia, 42.

AL-QalamNewspaer. (2003, November 28). Interview with a prominent Democratic Party Chief, Mustafa OuldAbeidRahman, 417.

Al Qarawi, M. S. (2013). The Memory of the Military Coups in Mauritania: the Struggle for Power, Mauritanian Journal of Political Science, 1.

Asfour, S. (2011). "The Military and the AKP: A New Confrontation Line in the Context of Turkeys Bid for Democratic Consolidation (Unpublished master's thesis) Cairo: American University.

Aslon, C. (2001). Party Building and democratization: the Case of Turkey (1983 - 1955). (Unpublished doctoral dissertation). Montreal: McGill University.

Bayoumi, S. (2005). A Military Coup in Mauritania. AfaaqAfricia Journal, 6(18), 135-142.

Belkeziz, A. (2005). The New Authority in Mauritania and the Challenges. Al Khaleej Al Emiratia.

Demirel, T. (2003). The Turkish Military's Decision to Intervene: 12 September 1980. Armed Forces and Society, 29(4).

Dipsar, F. V. G. (2008). Military Rule and Democracy in Greece and Turkey (Unpublished doctoral dissertation). Virginia: University of Virginia.

Donilof, A. F. (2001). The Army in Turkey: Politics and Coups, translated by Ypussef Al- Gahmani, Damascus: Horn House for Printing, Publishing and Distribution.

Doughan, G. (2006). Turkey. Turk Agency of Khabrer.

Eljmil, S. (1997). Arabs, Turks and Modernization: from Othonism to Secularism. Center for Arab Unity Studies.

Habib, S. K. (2006). The Political Parties in Turkey, A Study for the situation of Rofah Party (Unpublished doctoral dissertation). Cairo, Faculty of Economics and Political Science. 
Hassen, S. (2012). Secularism and Islamic Political Parties in Turky (Unpublished master's thesis). Cairo: Faculty of Economic and Political Science.

Mahfoud, A. S. (2008). The Argumentations of the State and Society in Turkey: The Military Establishment and the General Politics. Abu Dhabi: The Center of Emirates for Strategic Studies and research.

Mannaa, H. (2008, Nov. 12). The Military \& Democratic Foundation in Mauritania. Al Quds Al Arabi, 11, 15-17.

Mohamed, S. (2005). The Military Coup and the Crisis of Democracy in Mauritania, African Strategic Report.

Mohammed, A. J. (2011). Democracy and the Problem of Succession of Power in Mauritania 1991-2005, Journal of the University of Tikrit for Legal and Political Science, 3(10), 245-273.

Mohammed, Al-Jerfi. (2008, Aug 24). Morocco Has always Sought to Preserve Home. First Newspaper, 78, 6-8.

MohiEldeen, M. M. S. (2014). The Relationship between the Mechanisms of Power Rotation and the political Stability of African Countries since the End of the Cold War: Case Studies of Nigeria and Mauritania (unpublished doctoral dissertation). African Research and Studies Institut, Cairo, Egypt.

MohiEldeen, M. M. S. (April, 2014). Military Coups and Political Stability in Africa: Model of Mauritania". Al She'oeen Al Africia Journal, 2, 56-83.

Mountaser, M. M. (2015). The Impact of Civil - Militry Relation on Democratization: Comparative Analysis Turkey - Indinesia (Unpublished master's thesis). Cairo: Faculty of Economic and Political Science.

Mubarak, A. A. S. (2013). Political Instability in Mauritania and its Implications on the Foreign Policy towards the Maghreb countries 2005- 2010 (Unpublished master's thesis). Batana University, Algeria.

Ndiaye, B. (2006, April 15). Mauritania, August 2005: Justice and Democracy, or Just Another coup? African Affairs Journal, 105(420), 430-442.

NourEddin, M. (1989). Turkey, the Confused State Approaches to Religion, Political and Foreign Relations. Beirut, the Center of Strategic Studies, Research and Documentation.

OuldHaidalla, M. K. (2012). From the Palace to the Families: The President's experience with the longest political prison in Mauritania, Nouakchott: the Leaflets of the Independent News Agency.

OuldHarma, O. A. (2014). Army and Power in Mauritania. Casablanca: The Center of Al Sahaifa of Strategic Studies.

OuldSidi Bab, M. A. (2005). Coup of August 3, 2005 in Mauritania or Change from the Inside, Al Mustaqbal Al Arabi Journal, 320, 80-92.

Ozbudun, E. (2011). The constitutional system of turkey: 1876 to the present. New York: Palgrave Macmillan.

Rumpf, C. (2011). The military, the presidency, and the constitution: a comparative approach to the Weimar republic, France 1958, and turkey 1982, in state, democracy and the military: turkey in the 1980s, ed. MetinHeper and AhmetEvin (Berlin: Walter de Gruyter).

Shafei, B. H. (2006). Mauritania: the Win of the Independents. Democratia Journal, 23, 1-4.

Shafei, B. H. (2008). The Next Scenario in Mauritania. Al-Ahram Strategic File, 1-2.

Shetan, B. D. (1989). The Islamic Movement in Turkey. Cairo: Dar Al Zahraee for the Arab Media.

Stevens, D. C. (2009). Retreating Guardians, Social Legitimacy and the Survival of Military Prerogatives in Chile and Turkey (Unpublished doctoral dissertation). Columbia: Columia University.

Theracky, F. W. et al. (2001). The History of Turkey (Westport, (T: Greenwood Press).

Weiker, W. F. (1980). The Turkish Revolution 1960-1961: Aspects of Military Politics. Greenwood Press.

Zahra, H. (2016). The Military Withdrawal from Power a Comparative Study (Unpublished doctoral dissertation). Cairo: Faculty of Economic and Political Science.

Zucher, E. J. (2004). Turkey: A Modern History (3rd ed.). London and New York: I. B. Touris.

\section{Copyrights}

Copyright for this article is retained by the author(s), with first publication rights granted to the journal.

This is an open-access article distributed under the terms and conditions of the Creative Commons Attribution license (http://creativecommons.org/licenses/by/4.0/). 